\title{
Penerapan Teknologi Pengolahan Limbah Biomassa Menjadi Asap Cair di Desa Sungai Dua Banyuasin
}

\author{
(Application of Biomass Waste Treatment Technology Becomes Liquid Smoke in \\ Sungai Dua Village, Banyuasin) \\ Mariyamah $^{1}$, Nurul Kholidah ${ }^{2}$, Suci Permata Sari ${ }^{3}$ \\ ${ }^{1,2,3}$ Program Studi Kimia Fakultas Sains dan Teknologi Universitas Islam Negeri (UIN) Raden Fatah \\ Palembang - Jl. Prof. Zainal Abidin Fikri KM 3,5 Palembang
}

\section{ARTICLE INFO}

Article history

Received : 31 October 2020

Revised : 20 November 2020

Accepted : 24 November 2020

DOI :

http://dx.doi.org/10.33366/jast.v4i2.2053

\section{Keywords}

biomass;

pyrolysis;

liquid smoke

*e-mail corresponding author :

mariyamah_uin@radenfatah.ac.id

\section{(c) (i) (2)}

This is an open access article under the Creative Commons Attribution-ShareAlike 4.0 International License. Any further distribution of this work must maintain attribution to the author(s) and the title of the work, journal citation and DOI. CC-BY-SA

\section{ABSTRACT}

Sungai Dua Banyuasin village is dominated by agricultural and plantation crops, namely rice, rubber, and coconut. During the harvest period, biomass waste in rice husks, rubber seed shells, and coconut shells is very abundant and has not been used optimally. One of the technologies that can treat biomass waste is Unit Thermal Cracking. This tool uses pyrolysis technology so that it can process biomass waste into liquid smoke and charcoal. This activity aims to help the community process biomass waste and provide product solutions that can eliminate bad odors in the rubber processing process. Community service partners are the community, especially farmer groups and village officials in Sungai Dua Banyuasin. This service activity was carried out in several stages, including a) Counseling to provide information and increase understanding public in processing biomass waste, b) Diffusion of science and technology through the manufacture of Thermal Cracking Units, c) Training in running tools and making liquid smoke. This activity was followed by the community enthusiastically by making liquid smoke independently. At the end of the activity, the handover of equipment was carried out with Sungai Dua village officials

\section{PENDAHULUAN}

Kabupaten Banyuasin secara geografis mempunyai letak yang strategis yaitu terletak di jalur lintas antar provinsi dengan luas wilayah $11.832,69 \mathrm{~km}^{2}$ dan terbagi menjadi 21 kecamatan [1]. Salah satu kecamatannya yaitu kecamatan Rambutan. Jenis tanaman yang ada di kecamatan ini didominasi oleh tanaman karet, kelapa dan kelapa sawit. Dengan luas area masing-masing 5.232 ha karet, 1.055 ha kelapa dan 679 ha kelapa sawit pada tahun 2018 [2]. Dan di desa Sungai Dua, $80 \%$ mata pencaharian penduduk adalah petani dengan jenis tanaman padi.

Pada saat pemanenan, limbah yang dihasilkan cukup melimpah [3]. Salah satu limbahnya yaitu cangkang biji dari karet, sekam dari padi dan tempurung dari kelapa. Limbah biomassa ini belum dimanfaatkan secara optimal. Limbah biomassa merupakan bahan organik yang belum dapat diambil manfaatnya secara 
ekonomi sebelum dilakukan proses lebih lanjut/daur ulang. Limbah biomassa merupakan sumber energi dan bahan baku produk lainnya yang cukup besar potensinya untuk diolah lebih lanjut [4] dan dimanfaatkan sebesar 30-40\% [3].

Selain itu, menurut Suwastika, dkk [5],limbah dari hasil pertanian merupakan persoalan yang hingga kini belum teratasi sepenuhnya. Oleh karena itu diperlukan inovasi untuk mengolah limbah agar dapat dimanfaatkan secara maksimal.

Salah satu proses yang dapat dilakukan untuk pengolahan cangkang biji karet, sekam padi tempurung kelapa yaitu dengan proses pirolisis. Dengan proses ini, limbah biomassa dapat dikonversi menjadi asap cair.

Asap cair berasal dari pembakaran hemiselulosa, selulosa dan lignin dari limbah biomassa sehingga menghasilkan senyawa-senyawa yang memiliki efek antimikroba, antibakteri dan antioksidan. Asap cair merupakan larutan dispersi asap dalam air yang diperoleh melalui pengembunan asap melalui kondensasi.

Proses pirolisis merupakan proses pemanasan tanpa berhubungan dengan udara luar dengan suhu yang cukup tinggi sehingga akan terjadi proses penguraian yang tidak teratur dari bahan-bahan organik atau senyawa kompleks. Hasil dari proses ini yaitu padatan, cairan dan gas [6]

Dari sisi lain, untuk menghasilkan asap cair yang berkualitas dan rendemen asap cair yang optimal tentu ada beberapa faktor yang mempengaruhi proses pirolisis. Salah satu faktor yang sangat berpengaruh dalam meningkatkan kuantitas dan kualitas dari asap cair yaitu kinerja dari alat pirolisis (Unit Thermal
Cracking). Selain itu, faktor-faktor lain yang mempengaruhi seperti kondisi operasi (suhu dan waktu pirolisis) serta jenis limbah biomassa yang digunakan.

Menurut Putri dkk [7], merancang dan membuat alat pirolisis (pirolisator) dengan memanfaatkan tabung gas elpiji $12 \mathrm{~kg}$ dan melakukan uji kinerja alat untuk beberapa limbah pertanian. Proses pemanasan dilakukan dengan menggunakan kompor gas jumbo dengan sumber gas dari gas elpiji $3 \mathrm{~kg}$. Dari hasil pengujian alat diperoleh kapasitas kinerja alat penghasil asap cair untuk tempurung kelapa, tongkol jagung, sabut kelapa dan kulit buah kakao masing-masing sebesar 0.55; 0.08; 0.05; dan $0.09 \mathrm{~kg} / \mathrm{jam}$, sedangkan untuk rendemen asap cair masing-masing sebesar $45.05 ; 8.73 ; 8.44$; dan $18 \%$.

Dari segi kebermanfaatannya, asap cair dapat digunakan dalam bidang kesehatan bidang pertanian, kehutanan, kesehatan, industri karet dan industri kayu serta dalam bidang pangan. Dari sisi kesehatan, berdasarkan hasil penelitian Mariyamah [8], asap cair dari kayu pelawan memiliki potensi sebagai antioksidan karena asap cair ini memiliki kandungan fenol yang cukup tinggi.

Tujuan kegiatan pengabdian ini adalah untuk mengetahui respon masyarakat dan untuk membantu masyarakat dalam pengolahan limbah biomassa serta memberikan solusi produk yang dapat menghilangkan bau yang tidak sedap dalam pengolahan karet dengan bantuan Unit Thermal Cracking.

\section{METODE KEGIATAN}

Metode penelitian pengabdian yang digunakan yaitu metode Asset Based 
Community Development. Dengan metode ini, peneliti melihat dan memperhatikan aset apa saja yang ada di masyarakat tersebut sehingga dapat memberikan solusi dari permasalahan yang ada ataupun aset yang dapat dikembangkan. Penelitian pengabdian ini dilakukan dengan beberapa tahap yaitu pendidikan masyarakat yang berupa penyuluhan, difusi ipteks, pelatihan dan serah terima teknologi asap cair.

\section{- Penyuluhan Masyarakat}

Tahapan penyuluhan ini diawali dengan analisis kebutuhan masyarakat dengan tujuan mengetahui permasalahan yang ada terkait dengan limbah pertanian. Hasil analisis ini digunakan untuk menentukan topik awal dari kegiatan pengabdian yaitu pengelolaan limbah menjadi asap cair.

Kegiatan selanjutnya yaitu berupa penyuluhan. Sebelum pemaparan materi, peserta diberikan pretest terlebih dahulu untuk mengetahui pengetahuan masyarakt tentang asap cair.

\section{○ Difusi Ipteks}

Tahapan ini meliputi pembuatan peralatan pirolisis yaitu Unit Thermal Cracking yang akan digunakan untuk pengolahan limbah biomassa menjadi asap cair. Proses pembuatannya dilakukan di pasar Cinde Palembang.

\section{- Pelatihan dan Serah Terima}

Pelatihan ini meliputi pelatihan soft skill dan pelatihan dalam pembuatan asap cair. Tujuan kegiatan ini adalah memotivasi masyarakat dalam bekerja dan berpikir kreatif serta inovatif dalam mengolah limbah menjadi sesuatu yang bernilai guna dan jual dengan menggunakan Unit Thermal Cracking.

\section{KARYA UTAMA}

Beberapa tahap kegiatan pengabdian ini antara lain sebagai berikut :

\subsection{Penyuluhan}

Hasil yang didapat sebelum penyuluhan yaitu berupa wawancara dan Focus Group Discussion (FGD) dengan masyarakat. Hal ini untuk mengetahui potensi apa saja yang dimiliki di desa tersebut dan masalah apa saja yang terjadi. Selain itu, untuk melihat pemahaman masyarakat mengenai pengelolaan limbah yang telah dilakukan.

Sebelum melakukan FGD, dilakukan pre test terlebih dahulu. Hal ini dilakukan untuk melihat pemahaman awal masyarakat yang datang pada hari itu. Respon yang datang berasal dari berbagai elemen mulai dari unsur perangkat desa, kelompok tani dan masyarakat sekitar yang ada di desa Sungai Dua Banyuasin. Jumlah responden yang datang berjumlah 23 orang dengan sebaran umur seperti pada gambar 1. dan jenis kelamin pada gambar 2.

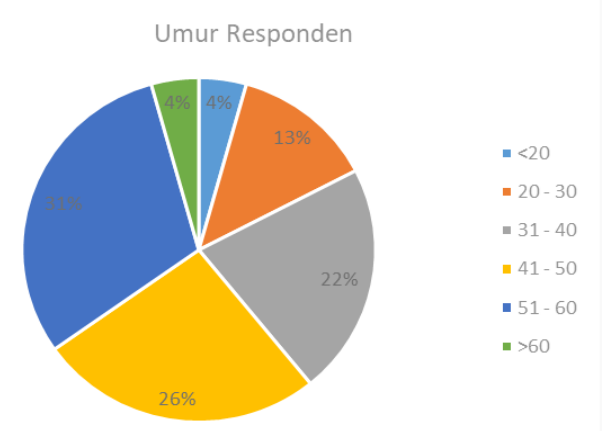

Gambar 1. Sebaran umur responden 


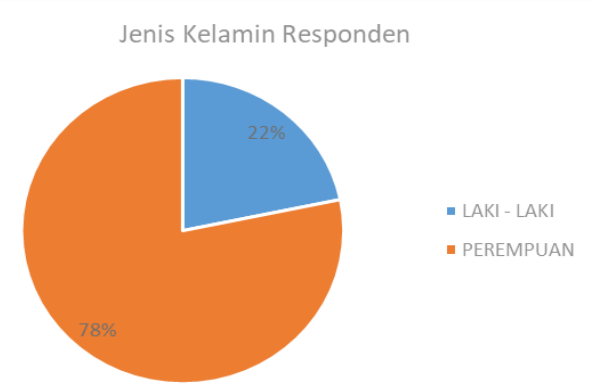

Gambar 2. Sebaran jenis kelamin responden

Dari gambar 1. terlihat bahwa sebaran umur masyarakat yang akan mengikuti pelatihan pengoperasian alat dari berbagai rentang umur dengan urutan yang paling besar yaitu $31 \%$ berusia (51 - 60) tahun, $26 \%$ berusia $(41-50)$ tahun dan $22 \%$ berusia (31 - 40) tahun. Dan dari gambar 6.2 sebaran jenis kelamin, perbandingan antara laki - laki dan perempuan yaitu 22 $\%$ dan $78 \%$.

\section{A. Pengetahuan tentang asap cair}

Untuk mengetahui pengetahuan masyarakat tentang asap cair maka dibuat pertanyaan apakah masyarakat pernah mendengar tentang asap cair. Dari hasil pre test menunjukkan bahwa $65 \%$ responden belum pernah mendengar tentang asap cair dan $35 \%$ sudah pernah mendengar tentang asap cair, seperti pada gambar 3 .

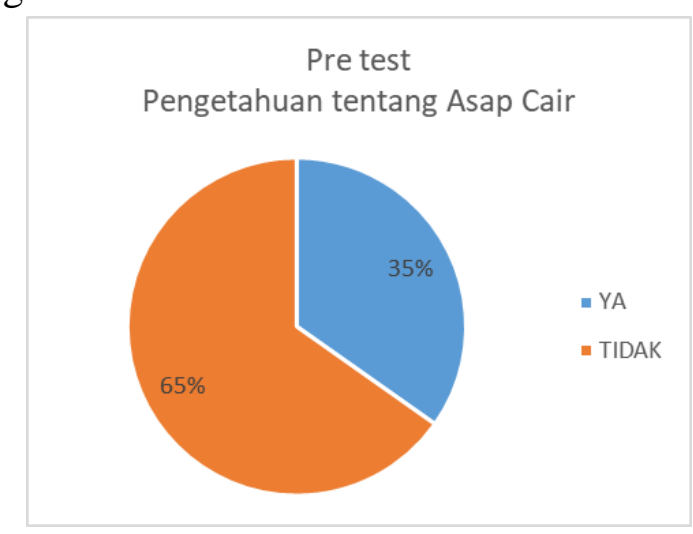

Gambar 3. Pre test pengetahuan tentang asap cair
B. Pengetahuan tentang proses pembuatan asap cair

Pre test untuk mengetahui pengetahuan masyarakat tentang poses pembuatan asap cair menunjukkan bahwa $65 \%$ responden tidak mengetahui proses pembuatan asap seperti pada gambar 4 .

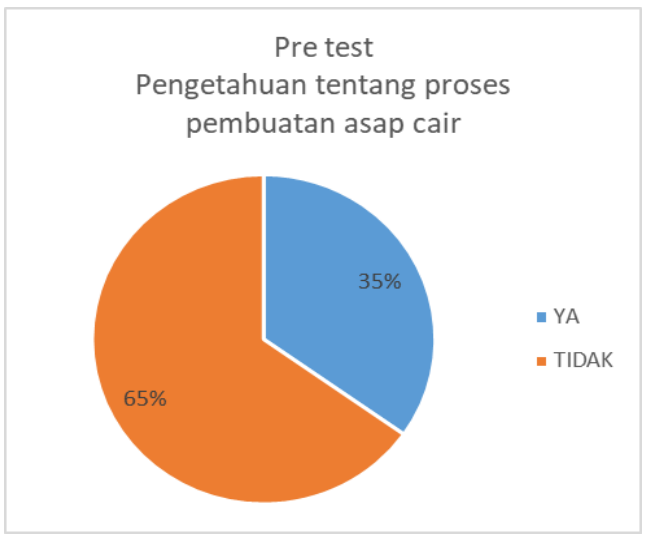

Gambar 4. Pre test pengetahuan tentang proses pembuatan asap cair

C. Pengetahuan tentang alat untuk membuat asap cair

Untuk mengetahui pengetahuan responden tentang alat yang bisa digunakan untuk membuat asap cair, setelah disebarkan pre test menunjukkan bahwa masih banyak responden yang belum mengetahui tentang alat yang bisa diguanakan untuk mengolah limbah biomassa menjadi asap cair. Hal itu terlihat dari gambar 5.

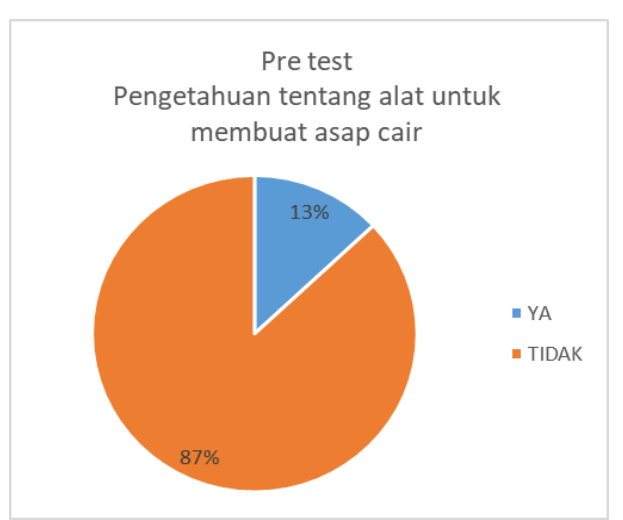

Gambar 5. Pre test pengetahuan tentang alat untuk membuat asap cair 
D. Pengetahuan tentang manfaat asap cair

Dari hasil pre test mengenai manfaat asap cair menunjukkan bahwa ternyata $70 \%$ responden tidak/belum mengetahui tentang manfaat asap cair, hal ini terlihat pada gambar 6

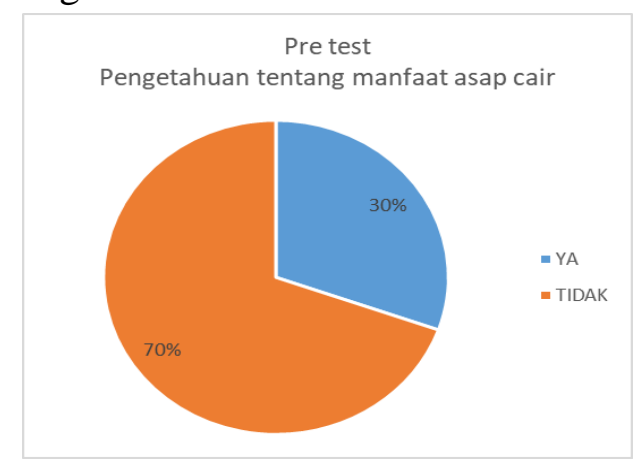

Gambar 6. Pre test pengetahuan tentang manfaat asap cair

Dan berdasarkan hasil dari wawancara dan FGD menunjukkan bahwa masih lumayan banyak limbah biomassa pertanian yang belum termanfaatkan secara optimal. Limbah - limbah tersebut yaitu sekam padi, tempurung kelapa dan tempurung biji karet.

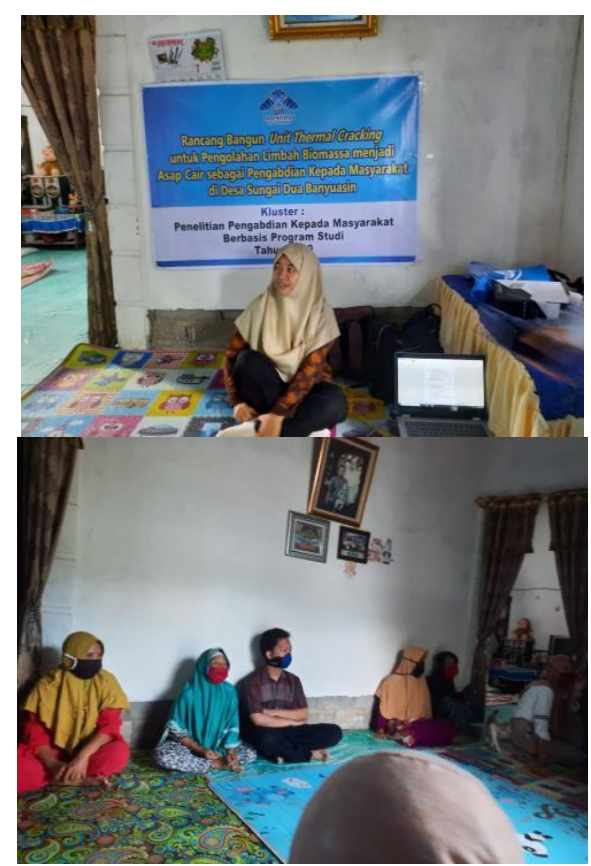

Gambar 7. Kegiatan Penyuluhan
Tahap selanjutnya yaitu penyuluhan. Tujuannya adalah untuk memberikan pengetahuan dan pemahaman tentang pengelolaan limbah pertanian menjadi asap cair dengan metode pirolisis. Metode pendekatan disemiasi dengan melihat kondisi dan potensi wilayah serta pendekatan pemberdayaan dengan tujuan menumbuhkan kemandirian masyarakat [9] Penyuluhan yang dilakukan yaitu berupa transfer pengetahuan kepada masyarakat mengenai limbah biomassa seperti sekam padi, tempurung kelapa dan tempurung biji karet yang potensial di Desa Sungai Dua Banyuasin dapat diolah menjadi bahan yang bernilai jual.

Pada kegiatan penyuluhan ini, masyarakat desa Sungai Dua sangat antusias dengan penjelasan yang berikan. Mereka sangat tertarik untuk mempraktikkan secara langsung asap cair yang akan dihasilkan karena mereka belum ada bayangan mengapa asap bisa berwujud cair padahal asap yang selama ini mereka kenal adalah asap yang berwujud gas. Selain itu, diterangkan juga manfaat yang luar biasa dari asap cair mulai dari pertanian dan kehutanan, kesehatan, industry karet maupun industry kayu bahkan untuk makanan juga dapat digunakan. Dengan diterangkannya manfaat asap cair ini, masyarakat lebih sangat antusias lagi untuk segera mempraktekkannya.

\subsection{Difusi Iptek}

Pada tahap ini, kami membawakan satu Unit Thermal Cracking untuk proses pirolisis asap cair. Karena untuk pembuatan alat ini tidak bisa dilakukan di desa sehingga hasil dari rancangan alat 
ditempakan di bengkel bubut di Palembang. Alat proses pirolisis ini dirancang untuk proses operasi yang miskin akan oksigen dan suhu yang tinggi. Sehingga keakuratan dari peralatan sangat menentukan jumlah asap cair yang dihasilkan. Adapun gambar Unit Thermal Cracking dapat dilihat pada gambar 8 .

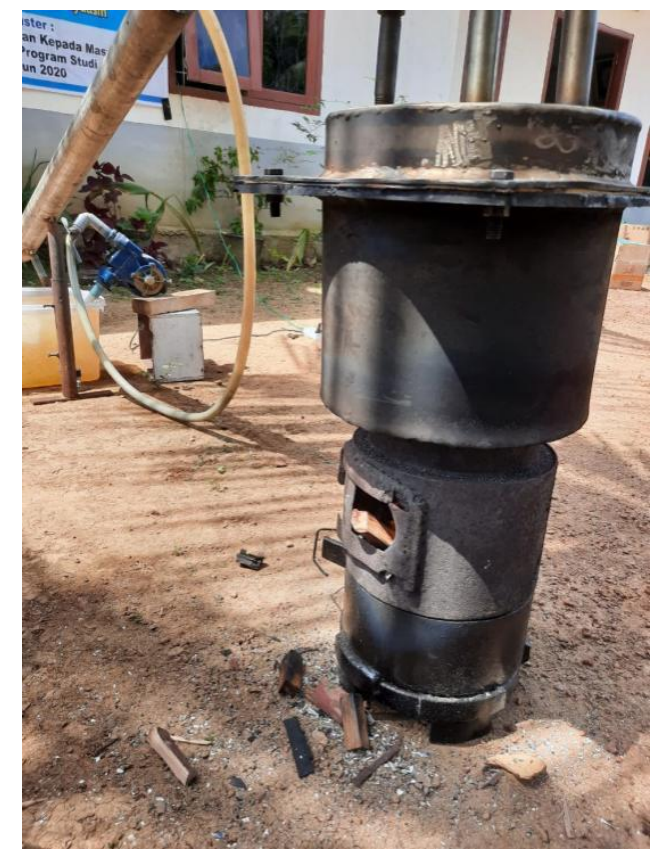

Gambar 8. Unit Thermal Cracking

Unit thermal cracking ini terdiri dari tungku pembakar yang berupa kompor biomassa dengan pasokan udara dibantu kompresor, reaktor yang berbentuk silinder yang dilengkapi pressure gauge dan temperature gauge, kondensor. Bahan reaktor dan pipa terbuat dari bahan stainless steel sedangkan kompor biomassa terbuat dari bahan besi cor.

\subsection{Pelatihan dan serah terima}

Sebelum memulai pelatihan, dijelaskan terlebih dahulu prosedur penggunaan dan perawatan Unit Thermal Cracking dalam pengolahan limbah biomassa menjadi asap cair. Pelatihan membuat asap cair ini dipraktekkan secara langsung oleh masyarakat.

Adapun unjuk kerja unit thermal cracking adalah sebagai berikut : Sebelum diproses limbah biomassa berupa cangkang biji karet / sekam padi / tempurung kelapa dibersihkan dan dikeringkan terlebih dahulu secara alami menggunakan sinar matahari. Pada tahap persiapan bahan baku, dilakukan pengecilan ukuran limbah biomassa dengan tujuan agar mempermudah proses pirolisis. Selanjutnya, limbah biomassa yang telah dikecilkan ukurannya sebanyak $4 \mathrm{~kg}$ dimasukkan ke dalam tabung pirolisator. Proses pemanasan dilakukan dengan menggunakan tungku pembakaran yang bahan bakarnya berasal dari limbah biomassa. Proses pirolisis dilakukan hingga asap cair tidak terbentuk lagi. Proses pirolisis dilakukan dengan memanaskan tabung pirolisator dengan tungku pembakaran biomassa. Uap yang terbentuk mengalir dari atas tabung pirolisator menuju kondenser, selanjtunya uap tersebut dikondensasi dan kemudian destilat yang dihasilkan ditampung. Destilat atau asap cair yang dihasilkan diukur volumenya dan dicatat. Selama melakukan pelatihan, masyarakat desa Sungai Dua sangat tertarik dan antusias. Hal ini terlihat dari banyaknya pertanyaan yang bermunculan dan keinginan masyarakat untuk melihat secara langsung tetesan pertama dari asap cair yang dihasilkan. Mereka juga ikut serta dalam mengoperasikan peralatan ini. Kegiatan pelatihan sesuai dengan SOP.

$$
\text { Selanjutnya yaitu kegiatan }
$$
pendampingan. Pendampingan sangat penting untuk menentukan keberhasilan dari kegiatan pengabdian. Pelaku 
pendamping sebagai fasilitator yang berarti pendamping menempatkan masyarakat senbagai pelaku utama sedangkan pendamping sebagai pembimbing [10].

Kegiatan ini disertai dengan kegiatan monitoring dan evaluasi. Tujuan kegiatan ini adalah untuk mengetahui perkembangan dan permasalahan serta memberikan solusi dari permasalahan tersebut. Dengan harapan masyarakat akan lebih terampil dalam mengoperasikan Unit Thermal Cracking sehingga masyarakat menjadi mandiri dalam proses produksi asap cair.

Setelah dilakukan pelatihan dan penyuluhan, akhirnya semua masyarakat yang hadir mengetahui tentang asap cair mulai dari proses pembuatan, alat yang digunakan serta manfaat asap cair.

Dari hasil survei juga menunjukkan bahwa masyarakat sangat setuju jika alat pengolahan limbah biomassa ini diberikan kepada masyarakat desa Sungai Dua. Dan di akhir kegiatan, dilakukan serah terima Unit Thermal Carcking dengan Ketua Kelompok Tani sekaligus Kasi Pemerintahan Desa Sungai Dua Banyuasin.

\section{ULASAN KARYA}

Asap cair memiliki banyak manfaat baik dalam bidang pertanian, kehutanan, kesehatan, industri karet dan industri kayu serta dalam bidang pangan. Dalam bidang pertanian dan kehutanan, asap cair dapat digunakan untuk memacu peningkatan jumlah mikrobayang berguana bagi tanah dan tanaman, menghambat pertumbuhan jamur, meningkatkan keberhasilan dalam penyemaian benih tanaman.
Dalam bidang kesehatan, asap cair dapat dimanfaatkan untuk menghilangkan gatal-gatal kulit dan sebagai detox (menghilang racun). Dalam bidang industri karet, dapat digunakan untuk penggumpalan lateks dan menghilangkan bau yang tidak sedap ketika mengolah karet. Sedangkan dalam bidang industry kayu dapat digunakan sebagai pengawet kayu. Selain itu, dalam bidang pangan, asap cair digunakan sebagai pengawet makanan seperti pengawet tahu ataupun ikan.

Dengan menggunakan peralatan ini, selain menghasilkan asap cair dihasilkan juga arang. Arang masih dapat dimanfaatkan masyarakat sebagai bahan bakar atau sebagai media tanam.

\section{DAMPAK DAN MANFAAT KEGIATAN}

Kegiatan pengabdian masyarakat yaitu berupa penerapan dan pelatihan Unit Thermal Cracking menunjukkan respon yang positif dengan terjadi peningkatan pengetahuan masyarakat. Peningkatan pengetahuan dan penyediaan teknologi ini diperlukan untuk membantu masyarakat dalam pengelolaan limbah biomassa dan memberikan solusi produk yang tepat dalam mengatasi bau yang tidak sedap selama proses penggumpalan karet.

Diharapkan kedepannya akan ada monitoring lanjutan hingga masyarakat dapat menghasilkan produk asap cair yang siap untuk dipasarkan. Tim pengabdian juga akan bekerjasama dengan Dinkes dan BPOM terkait sosialisasi dalam menjaga kualitas produk. 


\section{KESIMPULAN}

Setelah dilakukan serangkaian kegiatan pengabdian ini maka dapat disimpulkan bahwa terjadi peningkatan pengetahuan masyarakat dari $65 \%$ peserta belum mengenal asap cair dan $87 \%$ peserta belum mengetahui alat yang dapat mengolah limbah menjadi asap cair, menjadi semua peserta mengetahui tentang asap cair mulai dari proses pembuatan, alat yang digunakan serta manfaat asap cair. Selain itu, adanya kegiatan ini juga meningkatkan motivasi masyarakat untuk mengolah limbah biomassa dan menghasilkan asap cair yang memiliki nilai ekonomis.

\section{DAFTAR PUSTAKA}

[1] BPS Kabupaten Banyuasin, Ed., Kabupaten Banyuasin Dalam Angka 2020. BPS Kabupaten Banyuasin.

[2] Kecamatan rambutan dalam angka 2019. Banyuasin: Badan Pusat Statistik Kabupaten Banyuasin.

[3] L. Yunita, E. Marsudi, and S. Kasimin, "Pola Pemanfaatan Limbah Pertanian Untuk Usahatani Di Pidie Aceh," J. Ilm. Mhs. Pertan., vol. 1, no. 1, pp. 369-375, Nov. 2016.

[4] S. Slamet and T. Hidayat, "Studi Ek," Simetris J. Tek. Mesin, Elektro dan Ilmu Komput., vol. 6, no. 1, p. 189, Apr. 2015.
[5] A. A. N. G. S, N. W. S. S, A. A. A. A. S. S, N. N. S, and I. W. D. A, "Pengolahan Limbah Pertanian Dan Kerajinan Menjadi Pupuk Organik Berkualitas Di Desa Taro, Kecamatan Tegallalang Kabupaten Gianyar," vol. 12, no. 1, pp. 16-19, 2013.

[6] Putri and R. Eka, "Pengembangan Alat Penghasil Asap Cair dari Sekam Padi untuk Menghasilkan Insektisida Organik," J. Teknol. Pertan. Andalas, vol. 19, no. 2, 2015

[7] R. E. Putri, A. Kasim, and A. Asben, "Karakterisasi Kinerja Alat Pembuat Asap Cair Dari Biomassa Pertanian," Agrica Ekstensiall, vol. 12, no. 1, pp. 45-50, 2018.

[8] Mariyamah, Potensi Asap Cair Kayu Pelawan sebagai Antioksidan. Rafah Press, 2019.

[9] A. Rastono, R. Firgiyanto, P. R. Asih, E. Faustina, and D. Megasari, "Pelatihan dan Pendampingan Teknologi Asap Cair Menggunakan Limbah Pertanian di Kecamatan Parengan, Tuban," JPPM (Jurnal Pengabdi. dan Pemberdaya. Masyarakat), vol. 2, no. 2, p. 279, 2018.

[10] I. Maryani, A. Mustofa, and S. Jatmika "Efektivitas Pendampingan Kelompok Dalam Meningkatkan Motivasi Berwirausaha Peternak Sapi Perah," JPPM (Jurnal Pengabdi. dan Pemberdaya. Masyarakat), vol. 2, p. 7, 2018. 